\title{
Optimal management of groundwater pumping of the cache critical groundwater area, Arkansas
}

\author{
Haveen Rashid • Haydar Al-Shukri • \\ Hanan Mahdi
}

Received: 19 December 2013/Accepted: 3 March 2014/Published online: 18 March 2014

(C) The Author(s) 2014. This article is published with open access at Springerlink.com

\begin{abstract}
A simulation model for part of the Mississippi River Valley alluvial aquifer in the Cache area, Arkansas, was coupled with an optimization model to determine maximum optimal pumping from irrigation wells in the areas where cones of depression exist. Groundwater Vistas and Groundwater Management software were used for simulation and optimization model, respectively. The Cache area was designated as a critical groundwater area in 2009 due to the decline in its water level to below $50 \%$ of the saturated thickness of the aquifer. The optimization model was formulated with the objective of maximizing water production from wells subjected to minimum head constraints and drawdown constraints, while limiting groundwater withdrawals to a maximum of 100 and $200 \%$ of the rate pumped in 2010. Four different sets of managed wells were tested in Scenarios 1, 3 (938 wells) and Scenarios 2, 4 (3870 wells). The optimal pumping rates from groundwater in the case of minimum head constraints were 0.59 and $2.43 \mathrm{Mm}^{3} / \mathrm{d}$ for Scenarios 1 and 2, respectively. In the case of maximum pumping constraints of the managed wells specified as $200 \%$ of the pumping rate of 2010 ,
\end{abstract}

H. Rashid ( $₫)$

Dams and Water Resources Department, Faculty of Engineering, University of Sulaimani, Sulaymaniyah, Iraq

e-mail: hmrashid@ualr.edu

H. Rashid · H. Al-Shukri

Department of Applied Science, University of Arkansas, 2801 South University Ave, Little Rock, AR 72204, USA e-mail: hjalshukri@ualr.edu

H. Mahdi

Graduate Institute of Technology, University of Arkansas, 2801 South University Ave, Little Rock, AR 72204, USA e-mail: hhmahdi@ualr.edu the optimal pumping rates from groundwater in the case of minimum head constraints were 0.88 and $3.28 \mathrm{Mm}^{3} / \mathrm{d}$ for Scenarios 3 and 4 , respectively. The average optimal pumping increased by 6-49\% in the case of the maximum pumping constraint specified as $200 \%$ of the pumping rate of the year 2010 .

Keywords Groundwater flow · Modeling - Groundwater vistas $\cdot$ Optimization - Groundwater management

\section{Introduction}

The Mississippi River Valley alluvial aquifer, often termed the "alluvial aquifer," ranked third in the nation for total groundwater withdrawals (Maupin and Barber 2005). Pumping of groundwater from the alluvial aquifer for agriculture started in the early 1900s in the Grand Prairie area for the irrigation of rice and soybeans. The first documentation of water level declines in the alluvial aquifer occurred in 1927 (Engler et al. 1945; Czarnecki 2010). Due to the heavy demands placed on the aquifer for irrigation, two major cones of depression were formed in the potentiometric surface in the Cache study area in this aquifer as documented by previous studies (Reed 2004; Schrader T 2006, 2008, 2010). The first one is in Poinsett and Cross counties (northern cone), and the second in St. Francis, Lee, and Monroe counties (southern cone) (Fig. 1).

The first effort to optimize groundwater withdrawals from the alluvial aquifer was conducted by Peralta and others (Peralta R et al. 1985) who estimated future groundwater availability in the Grand Prairie area. Peralta et al. (1991b) developed deterministic distributed parameter Simulation/Optimization computer models for each of the response matrix (RM) and embedding (EM) approaches 


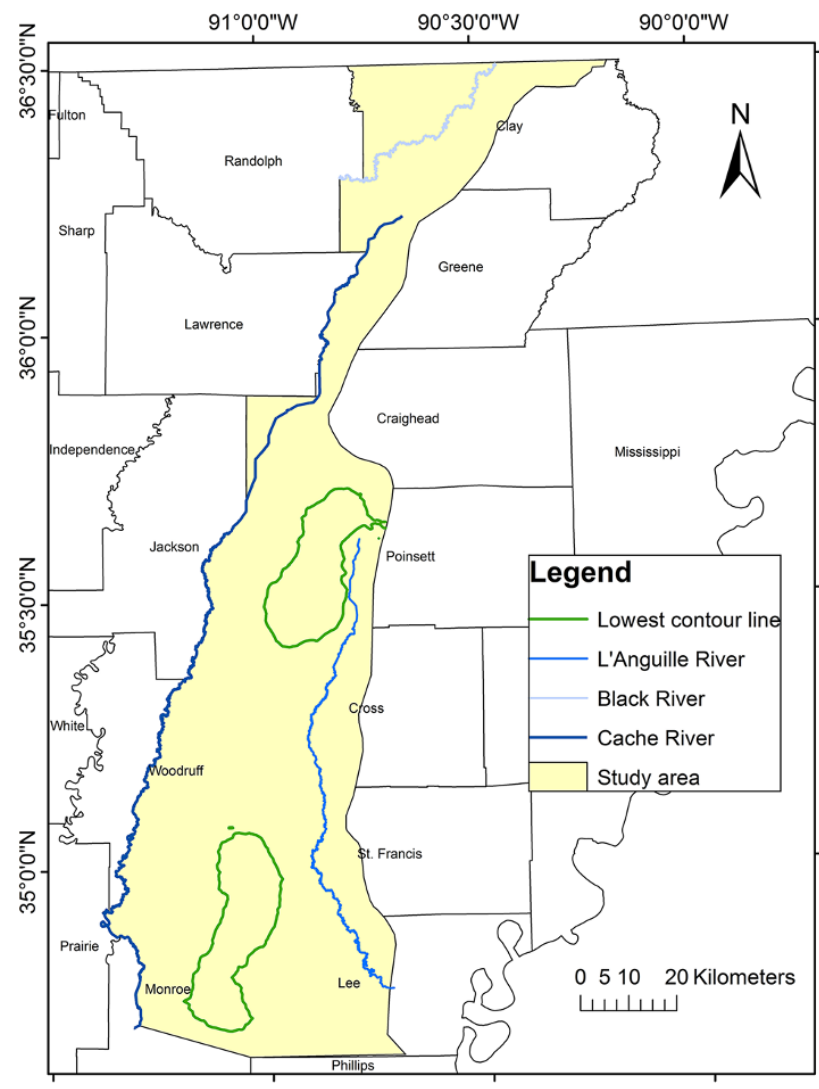

Fig. 1 Location of study area for computing maximum steady-state groundwater extraction strategies in a hypothetical confined aquifer. Two scenarios were tested in which recharge into the area was unconstrained and restricted. Both EM and RM models computed the same optimal pumping strategies. As a result, if heads must be restricted at many locations, or there are many pumping cells, the embedding approach is preferred to the response matrix approach for computing sustained yield groundwater pumping strategies for confined aquifers. Peralta et al. (1995) presented conjunctive water-use strategies for the alluvial aquifer in northeastern Arkansas using the sequential steady-state embedding approach for the five decades of 1990-2039. The effect of the aquifer parameter on the conjunctive use strategy was tested by changing hydraulic conductivity and river conductance. Changing hydraulic conductivity by $\pm 20 \%$ caused about $3 \%$ change in total provided water. Similarly, changing river conductance caused a $3 \%$ change in total provided water.

Barlow et al. (2003) developed conjunctive use management models for estimating sustainable yield from surface water and groundwater for two alluvial valley stream aquifer systems that were representative of those of the northeastern United States. The first was a hypothetical system for a typical stream aquifer system and the second was a stream aquifer system in central Rhode Island. Outcome from management model showed that current

Table 1 Detailed summary of the simulation model, in which "residual" refers to the difference between the observed and simulated hydraulic head, RMSE to root mean square error, and NGVD to National Geodetic Vertical Datum

\begin{tabular}{|c|c|c|c|c|c|c|c|}
\hline \multicolumn{2}{|l|}{ Grid } & \multicolumn{2}{|c|}{ Boundary conditions } & \multicolumn{2}{|l|}{ Target types } & \multicolumn{2}{|l|}{ Wells/statistics } \\
\hline Rows & 294 & Constant heads & 159 & Head & 150 & Analytical wells & 12,078 \\
\hline Columns & 149 & & & $\begin{array}{l}\text { Min head } \\
\text { constraints }\end{array}$ & $\begin{array}{l}134 \\
260 \\
220 \\
436\end{array}$ & & \\
\hline Layer & 1 & & & $\begin{array}{l}\text { Max drawdown } \\
\text { constraints }\end{array}$ & $\begin{array}{l}134 \\
260 \\
220 \\
436\end{array}$ & Boundary condition wells & 7,288 \\
\hline $\begin{array}{l}\text { Total Cells } \\
\text { Active Cells } \\
\text { Total Area }\end{array}$ & $\begin{array}{l}43,806 \\
13,742 \\
21,896 \mathrm{~km}^{2}\end{array}$ & Rivers & 675 & Kx Pilot point & 218 & $\begin{array}{l}\text { Mean residual for the } \\
\text { entire model simulation }\end{array}$ & $-0.27 \mathrm{~m}$ \\
\hline $\begin{array}{l}\text { Active Area } \\
\text { Row Spacing }\end{array}$ & $\begin{array}{l}6,869 \mathrm{~km}^{2} \\
707 \mathrm{~m}\end{array}$ & No flow & 30,064 & Storage Pilot point & 218 & RMSE & $1.18 \mathrm{~m}$ \\
\hline Column Spacing & $707 \mathrm{~m}$ & & & Recharge Pilot point & 218 & $\begin{array}{l}\text { Range of observations } \\
\text { hydraulic head above NGVD } 1929\end{array}$ & $48.84 \mathrm{~m}$ \\
\hline
\end{tabular}




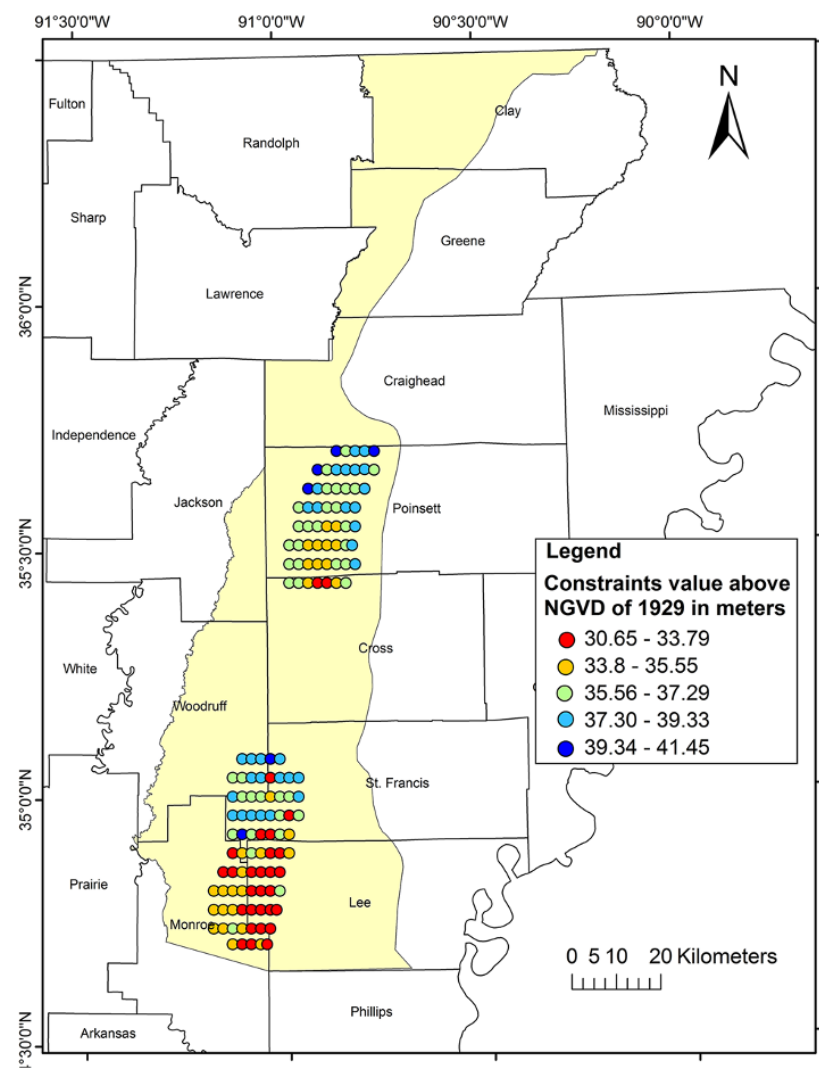

Fig. 2 Minimum head constraints for Sub-scenarios 1A, 3A (134 constraints)

withdrawal from aquifer increased by $50 \%$ by adjusting current withdrawal schedules, adjusting the number and arrangement of wells in the supply well network, or increased stream flow depletion in the Annaquatucket and Pettaquamscutt rivers.

Czarnecki J et al. (2003a) developed a conjunctive use optimization model based on Reed's model (Reed 2003) for the alluvial aquifer in northeastern Arkansas. The strategy for solving the problem was formulated to maximize the sustainable yield from all groundwater and surface water withdrawal rates within specified constraints involving hydraulic head and stream flow. Czarnecki J (2006) evaluated the effects of varying groundwater level constraints and river withdrawal specifications of the conjunctive use optimization model using four different management scenarios for the model described in Czarnecki $\mathbf{J}$ et al. (2003a). Average differences in sustainable yield of groundwater in Scenarios 2, 3, and 4 in comparison to Scenario 1 showed an increase of $6.74,6.82$, and $13.24 \%$, respectively. Czarnecki J (2008) utilized the existing conjunctive optimization model described in Czarnecki J (2006) to evaluate the effect of varying (1)

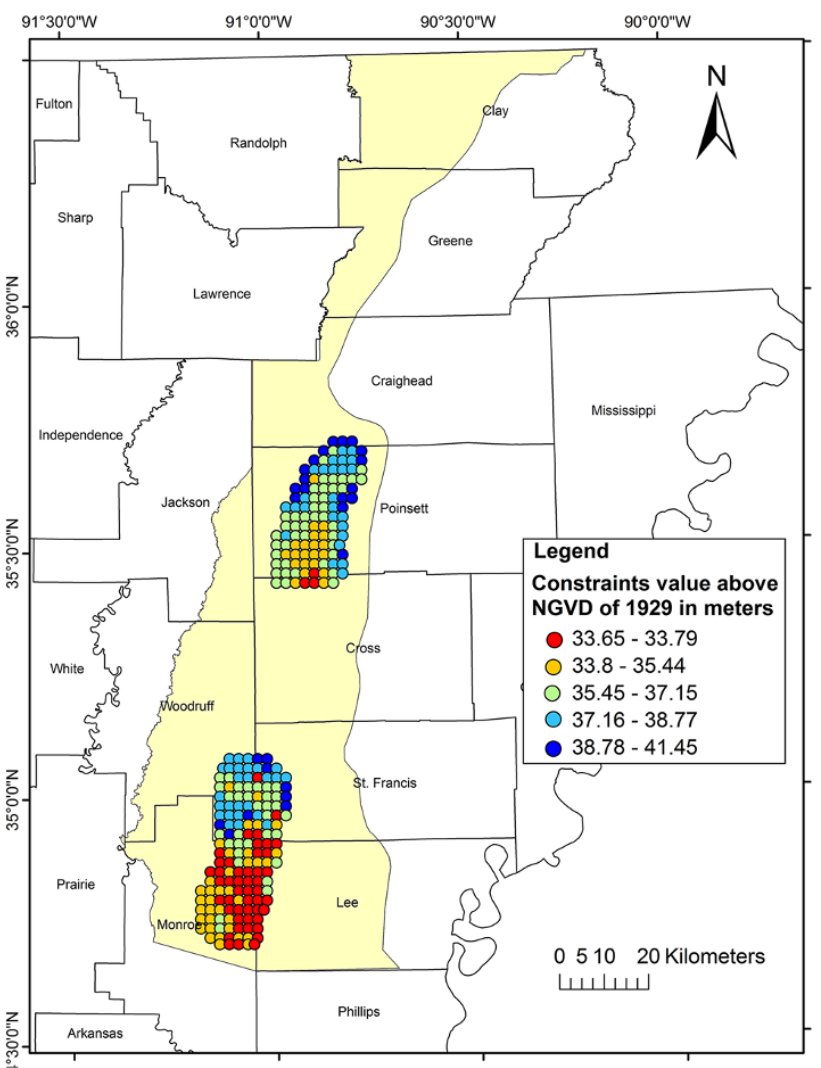

Fig. 3 Minimum head constraints for Sub-scenarios 1C, 3C (260 constraints)

the upper limit of groundwater withdrawal rates by reducing them to 75,50 , and $25 \%$ of the 1997 groundwater withdrawal rates; (2) the stream flow constraint associated with the White River representing minimum specified flow rates, and (3) the specified stage of the White River. The results indicated that, as the upper limit is reduced, the distribution of cells with sustainable yields greater than zero increases.

This study concentrates on the irrigation well optimization only without coupling stream flow optimization. In addition, the management model is limited to the wells located in Poinsett, Cross, St. Francis, Lee, Monroe, and Woodruff counties. Furthermore, different software was used for coupling the simulating model with the optimization model.

A management model of the Mississippi River Valley alluvial aquifer in the Cache Critical Groundwater Area was developed to estimate the optimal withdrawal rates that could be sustained for the wells located in the areas of the cones of depression under Arkansas Soil and Water Conservation Commission (ASWCC) policy constraints. The optimization model to be formulated with the objective 


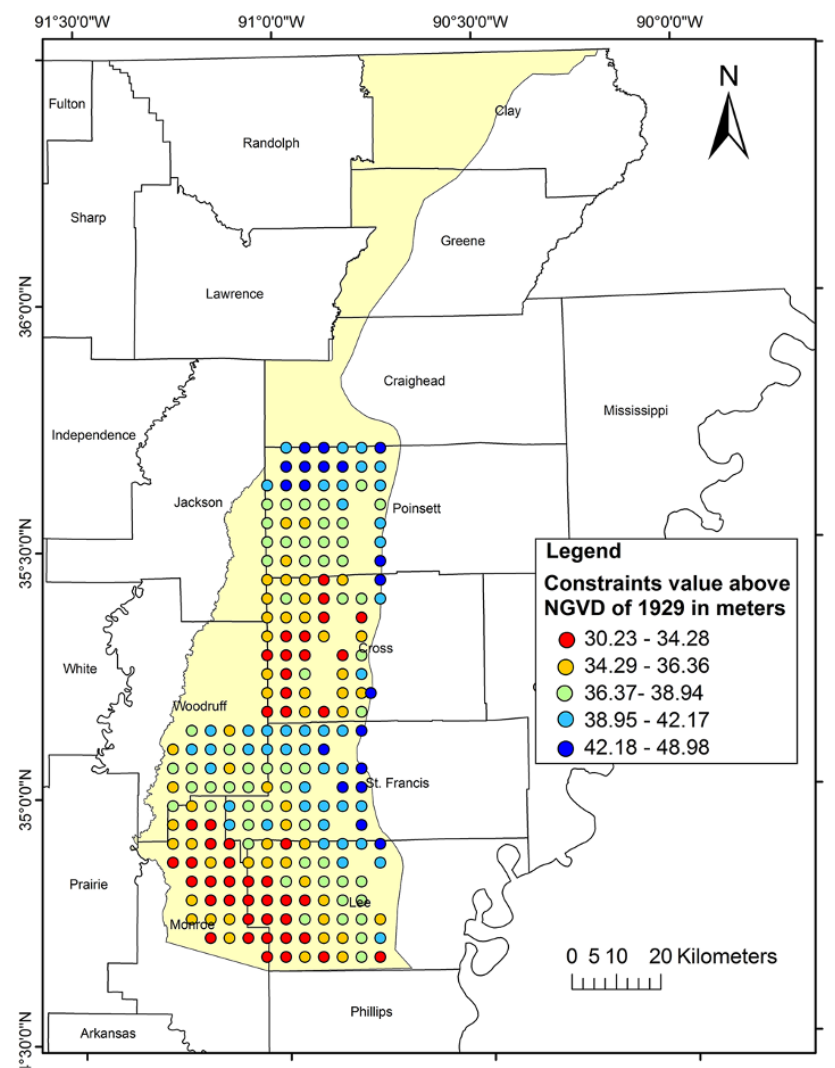

Fig. 4 Minimum head constraints for Sub-scenarios 2A, 4A (220 constraints)

of maximizing water production from wells will be subject to:

(a) maintaining groundwater levels at or above specified levels;

(b) maintaining the drawdown in water levels at or above minimum specified levels; and

(c) limiting groundwater withdrawals to a maximum of 100 and $200 \%$ of the rate pumped in 2010 using transient flow conditions.

\section{Method}

The study and model area is $6,869 \mathrm{~km}^{2}$ and is bounded by Crowleys ridge on the east, the Cache River to the west, the Arkansas Stateline to the north, and Lee County to the south (Fig. 1). It includes part of Clay, Greene, Craighead, Cross, Poinsett, St. Francis, Lee, Monroe, Woodruff, and Jackson Counties and is located between latitudes $34^{\circ} 39^{\prime} 1^{\prime \prime}$ to $36^{\circ} 29^{\prime} 53^{\prime \prime}$ North and longitudes $90^{\circ} 10^{\prime} 56^{\prime \prime}$ to $91^{\circ} 23^{\prime} 42^{\prime \prime}$ West. Three rivers are located within the study area: the Cache River, the L'Anguille River, and the Black River.

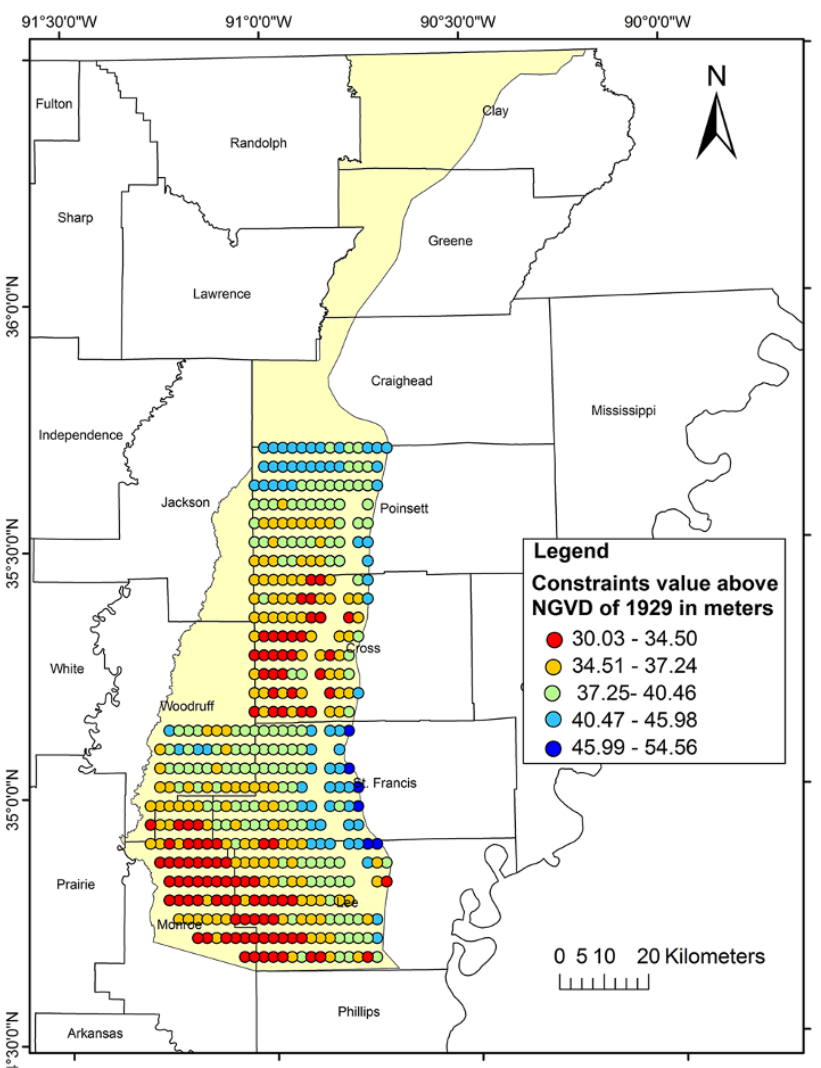

Fig. 5 Minimum head constraints for Sub-scenarios 2C, 4C (436 constraints)

Mean annual precipitation for the years 2000-2010 was approximately 1,219 $\mathrm{mm}$ (PRISM Group 2012). The normal annual temperature for the area is about $60{ }^{\circ} \mathrm{F}$ (Broom and Lyford 1981; PRISM Group 2012). The dominant land use in the area consists of cultivated crops (almost $90 \%$ of the area) such as rice, corn, soybeans, cotton, sorghum, and wheat (U.S. Department of Agriculture 2010).

A numerical finite-difference model was constructed using Groundwater Vistas (version 6.32). The MODFLOW 2000 (Harbaugh et al. 2000; Hill et al. 2000) and the Preconditioned Conjugate-Gradient Method (PCG2) solver (Hill 1990) were used for simulations. The finite-difference grid consists of 294 rows, 149 columns, and a single layer with cells that are $0.5 \mathrm{~km}^{2}$. The simulation period is from 2000 to 2010 with 23 stress periods modeled under transient flow conditions. The model was calibrated using the parameter estimation code (PEST). Additional calibration was achieved using pilot points with regularization and singular value decomposition (SVD-assist). Note the detailed information about the simulation model shown in Table 1.

The Groundwater Management (GWM) Process for the United States Geological Survey simulates three a dimensional groundwater model and MODFLOW-2000 and 2005 


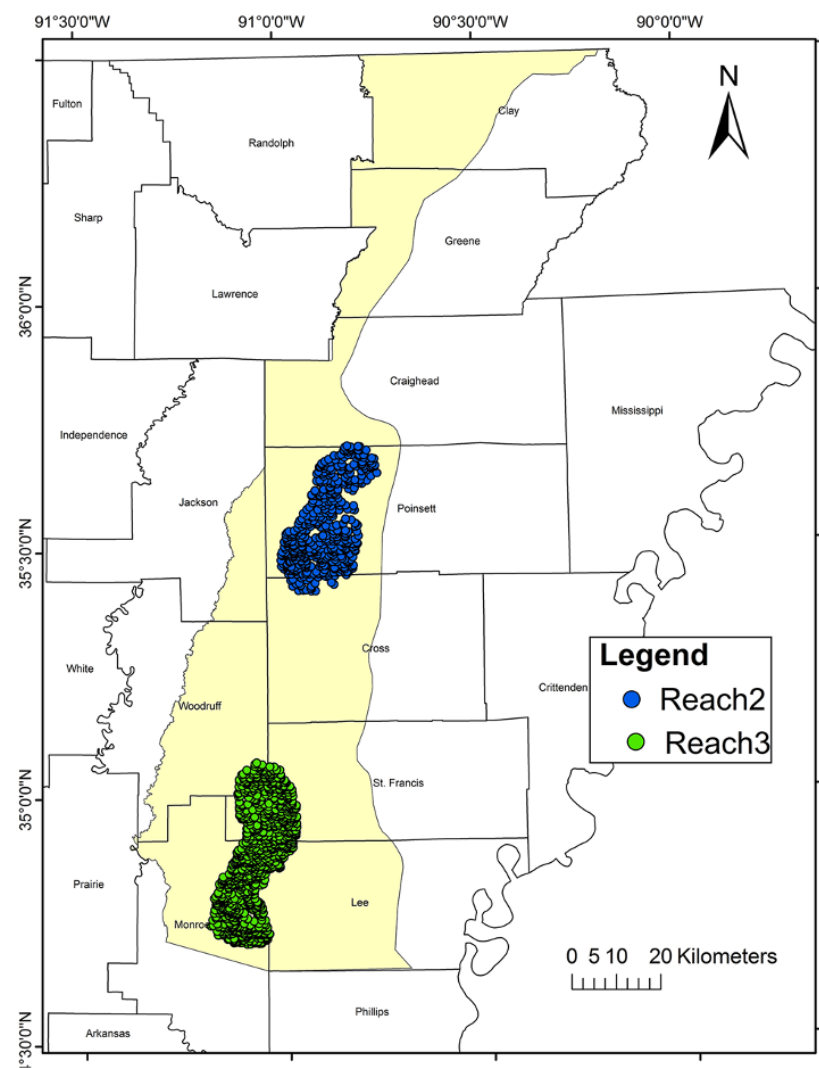

Fig. 6 Location of managed wells for scenarios 1 and 3

were used for optimization models. GWM solves several groundwater management formulations, such as linear, nonlinear, and mixed binary linear, using a response matrix approach. The response matrix solution (RMS) package of GWM uses the groundwater flow process of MODFLOW to calculate the change in head at each constraint location that results from a perturbation of a flow rate variable. These changes are used to calculate the response coefficients (Ahlfeld D et al. 2005). Each management formulation consists of an objective function, a set of constraints, and a set of decision variables. Together, these three components define a mathematical model of the management decision making process (Ahlfeld and Mulligan 2000; Kharmah 2007).

The objective function

The required objective function is to maximize total pumping from the managed wells. The objective function can be expressed as follows:

$\max \sum_{n=1}^{N} \beta_{n} Q w_{n} T_{Q w n}$

where $\sum_{n=1}^{N} \beta_{n} Q w_{n} T_{Q w n}$ is the sum of the weighted annual groundwater pumping rates from all the managed wells; $Q w_{n}$ is a pumping rate from well $\mathrm{n}$ of the year 2010; and $\beta_{n}$

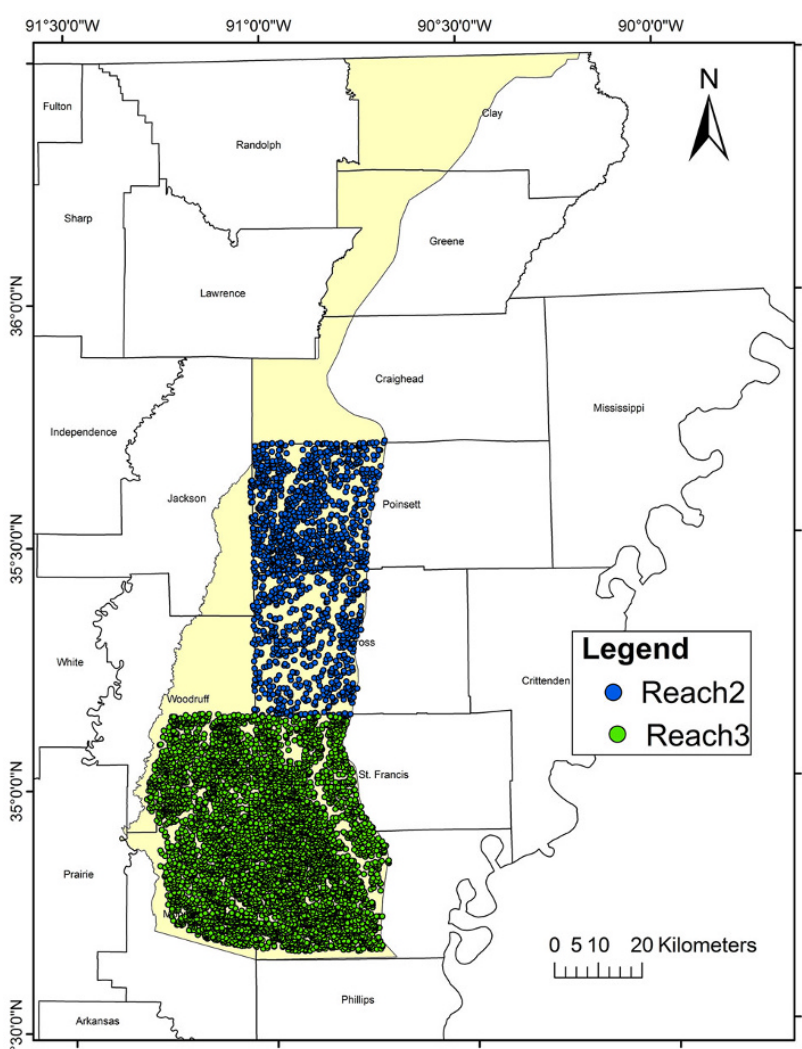

Fig. 7 Location of managed wells for scenarios 2 and 4

Table 2 Details of management scenarios, in which Hmin is the minimum head constraints and Dd is drawdown constraints

\begin{tabular}{|c|c|c|c|c|}
\hline Scenarios & $\begin{array}{l}\text { Sub- } \\
\text { scenarios }\end{array}$ & $\begin{array}{l}\text { Constraints } \\
\text { no. and type }\end{array}$ & $\begin{array}{l}\text { Decision } \\
\text { variables no. } \\
\text { (managed wells) }\end{array}$ & $\begin{array}{l}\text { Pumping } \\
\text { constraint }\end{array}$ \\
\hline \multirow[t]{4}{*}{1} & $1 \mathrm{~A}$ & 134-Hmin & 938 & $\begin{array}{l}100 \% \text { of the } \\
\text { pumping rate } \\
\text { of } 2010\end{array}$ \\
\hline & 1B & 134-Dd & & \\
\hline & $1 \mathrm{C}$ & 260-Hmin & & \\
\hline & $1 \mathrm{D}$ & 260-Dd & & \\
\hline \multirow[t]{4}{*}{2} & $2 \mathrm{~A}$ & 220-Hmin & 3,870 & \\
\hline & $2 B$ & 220-Dd & & \\
\hline & $2 \mathrm{C}$ & 436-Hmin & & \\
\hline & $2 \mathrm{D}$ & 436-Dd & & \\
\hline \multirow[t]{4}{*}{3} & $3 \mathrm{~A}$ & 134-Hmin & 938 & $\begin{array}{l}200 \% \text { of the } \\
\text { pumping rate } \\
\text { of } 2010\end{array}$ \\
\hline & $3 B$ & 134-Dd & & \\
\hline & $3 \mathrm{C}$ & 260-Hmin & & \\
\hline & $3 \mathrm{D}$ & 260-Dd & & \\
\hline \multirow[t]{4}{*}{4} & $4 \mathrm{~A}$ & 220-Hmin & 3,870 & \\
\hline & $4 B$ & 220-Dd & & \\
\hline & $4 \mathrm{C}$ & 436-Hmin & & \\
\hline & 4D & 436-Dd & & \\
\hline
\end{tabular}




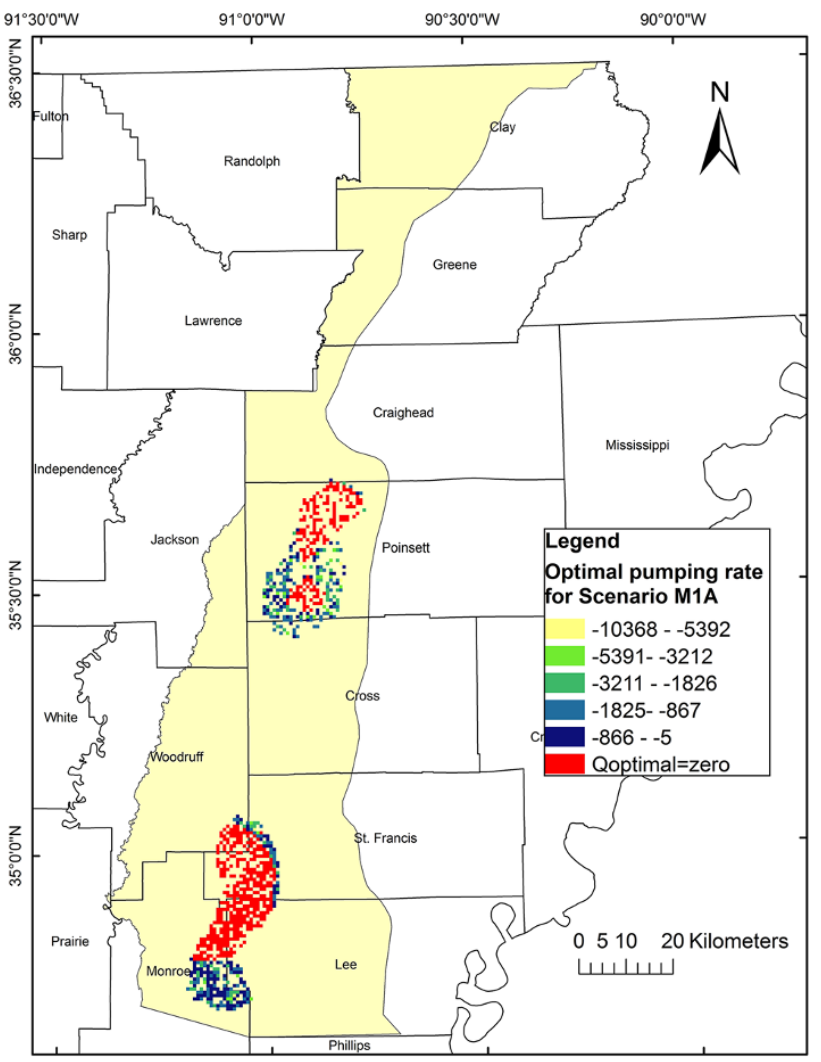

Fig. 8 Optimal pumping rate in $\mathrm{m}^{3} / \mathrm{d}$ for Sub-scenario 1A (134 min head constraints)

is the weight associated with annual groundwater pumping rate $Q w_{n} ; T_{Q w n}$ is the total duration of active flow at well site $n$. $\beta_{n}$ sets to the dimensionless values of 1.0.

\section{Model constraints}

\section{Hydraulic Head constraints}

The first type of constraint used is an absolute lower bound (minimum head constraint) placed on a head at a specific location:

$h_{i, j, k, t} \geq h_{i, j, k, t}^{l}$

where $h_{i, j, k, t}^{l}$, is the specified lower bound on head at locations $i, j, k$ at the end of the stress period $t$ were set at $50 \%$ of the predevelopment saturated thickness of the alluvial aquifer. This is to prevent the head from dropping below the $50 \%$ of initial saturated thickness. Minimum head constraints were calculated by taking half of the saturated thickness in each cell and adding the bottom elevation to it, to accommodate the ASWCC critical groundwater area criteria that water levels within the

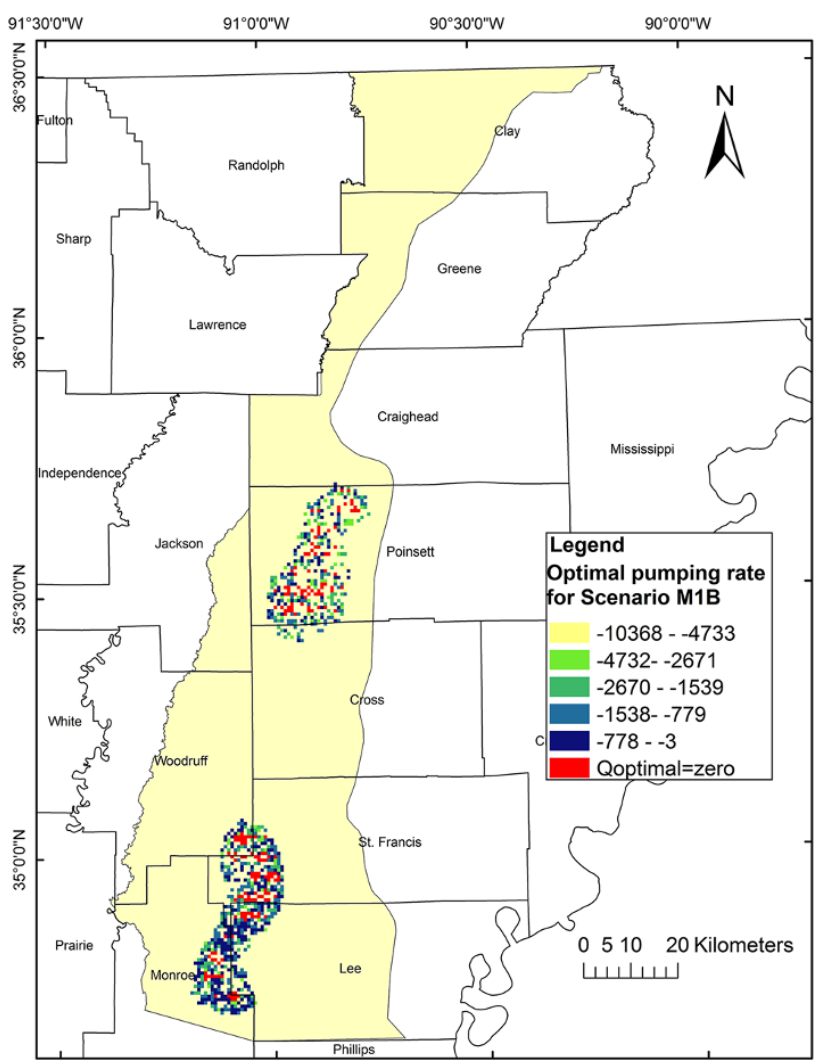

Fig. 9 Optimal pumping rate in $\mathrm{m}^{3} / \mathrm{d}$ for Sub-scenario 1B (134 drawdown constraints)

alluvial aquifer should remain above half the original saturated thickness of the aquifer. Four different sets of constraints were chosen: two set $(134,260)$ constraints for scenario 1 and 3 as shown in Figs. 2 and 3, and two set $(220,436)$ constraints for scenario 2 and 4 as shown in Figs. 4 and 5. The distribution of 134, 260 constraints was in the areas enclosed of the northern and southern cones every 3 cells horizontally and every 6,3 cells vertically for 134 and 260, respectively. The distribution of 220, 436 constraints was in the areas enclosed in Poinsett, Cross, St. Francis, Lee, Monroe, and part of Woodruff Counties every 6, 3 cells horizontally for 220 and 436, respectively, and every 6 cells vertically. The constraints value ranged between 30.03 and $54.56 \mathrm{~m}$.

\section{Drawdown constraints}

The second type of head constraint used was drawdown of head at a specific location. Drawdowns are defined by $d d_{i, j, k, t}$ and are equal to the difference between an initial head at locations $i, j, k$ at the end of stress period $t,\left(h_{i, j, k, t}\right)^{\circ}$, and the head calculated at the location at the end of the 


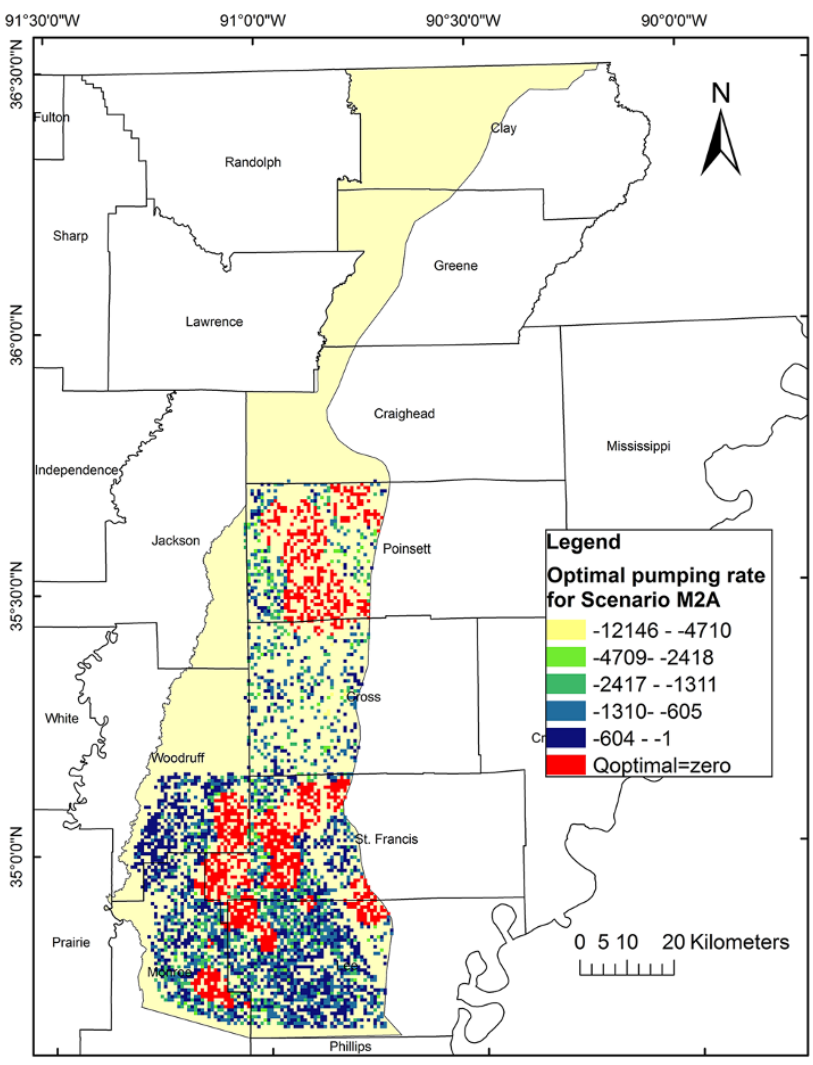

Fig. 10 Optimal pumping rate in $\mathrm{m}^{3} / \mathrm{d}$ for Sub-scenario 2A (220 min head constraints)

stress period after implementation of the optimal management strategy, $h_{i, j, k, t}$ :

$d d_{i, j, k, t}=\left(h_{i, j, k, t}\right)^{\circ}-h_{i, j, k, t}$

The drawdown constraints are written as.

$d d_{i, j, k, t} \leq d d_{i, j, k, t}^{u}$

where $d d_{i, j, k, t}^{u}$ is the specified upper bound on drawdown at locations $i, j, k$ at the end of stress period $t$. The optional value of each drawdown constraint was $2 \mathrm{~m}$, which was specified at the same location of the minimum head constraints.

\section{Groundwater withdrawal constraints}

$Q w_{n}^{l} \leq Q w_{n} \leq Q w_{n}^{u}$

where $Q w_{n}^{l}$ and $Q w_{n}^{u}$ are the lower and upper bounds on flow rate decision variable, respectively. $Q w_{n}^{l}$ is equal to zero, and $Q w_{n}^{u}$ is equal to $100 \%$ flow rate of the year 2010 and $200 \%$ of flow rate of the year 2010 .

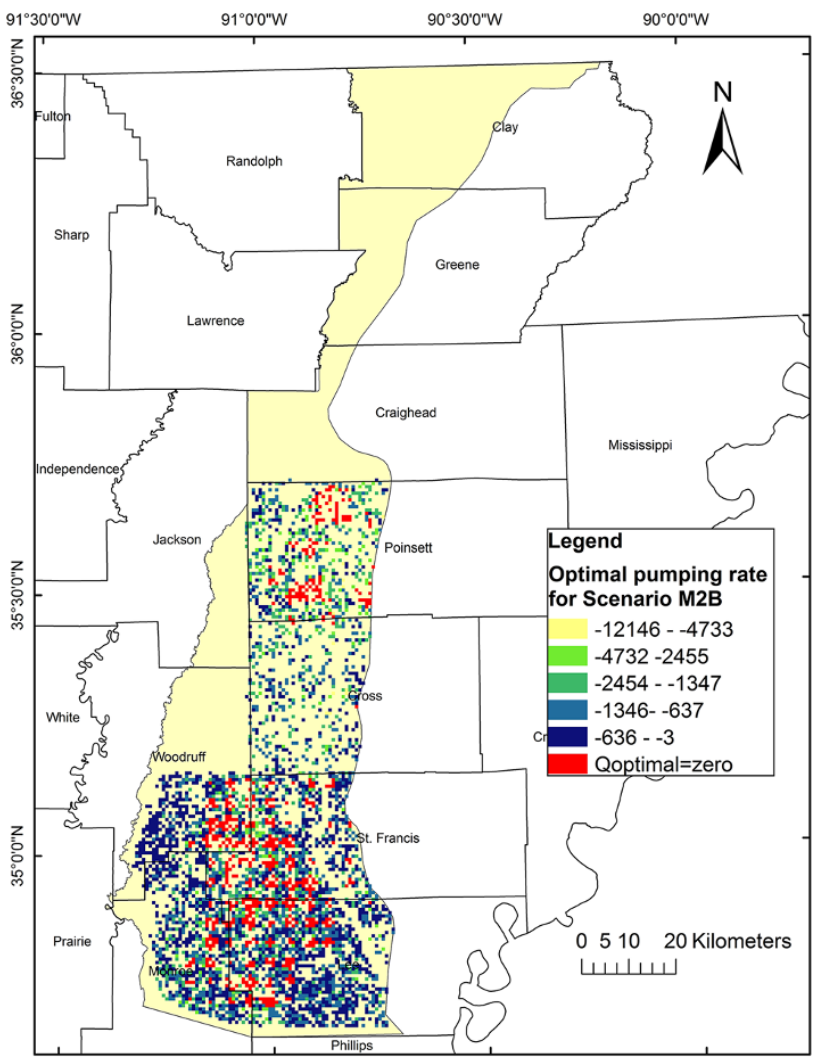

Fig. 11 Optimal pumping rate in $\mathrm{m}^{3} / \mathrm{d}$ for Sub-scenario 2B (220 drawdown constraints)

Decision variables and management scenarios

Four different sets of decision variables (managed wells) were tested. Scenarios 1 and 3 (938 managed wells) were located in the two areas enclosed by the lowest contour value for the year 2010 (northern cone and southern cone) as shown in (Fig. 6), and Scenarios 2 and 4 (3,870 managed wells) were located in the areas enclosed in Poinsett, Cross, St. Francis, Lee, Monroe, and part of Woodruff Counties as shown in (Fig. 7). The managed wells were selected based on the continuous water level declines at those locations. The irrigation wells located within a single cell were aggregated and represented in a single decision variable (single managed well). Each of the four scenarios represented in four sub-scenarios to find the optimal pumping in the selected wells as shown in Table 2.

\section{Optimization formulation}

The optimization model was formulated as a sequential linear programing (SLP) problem to address the aquifer 


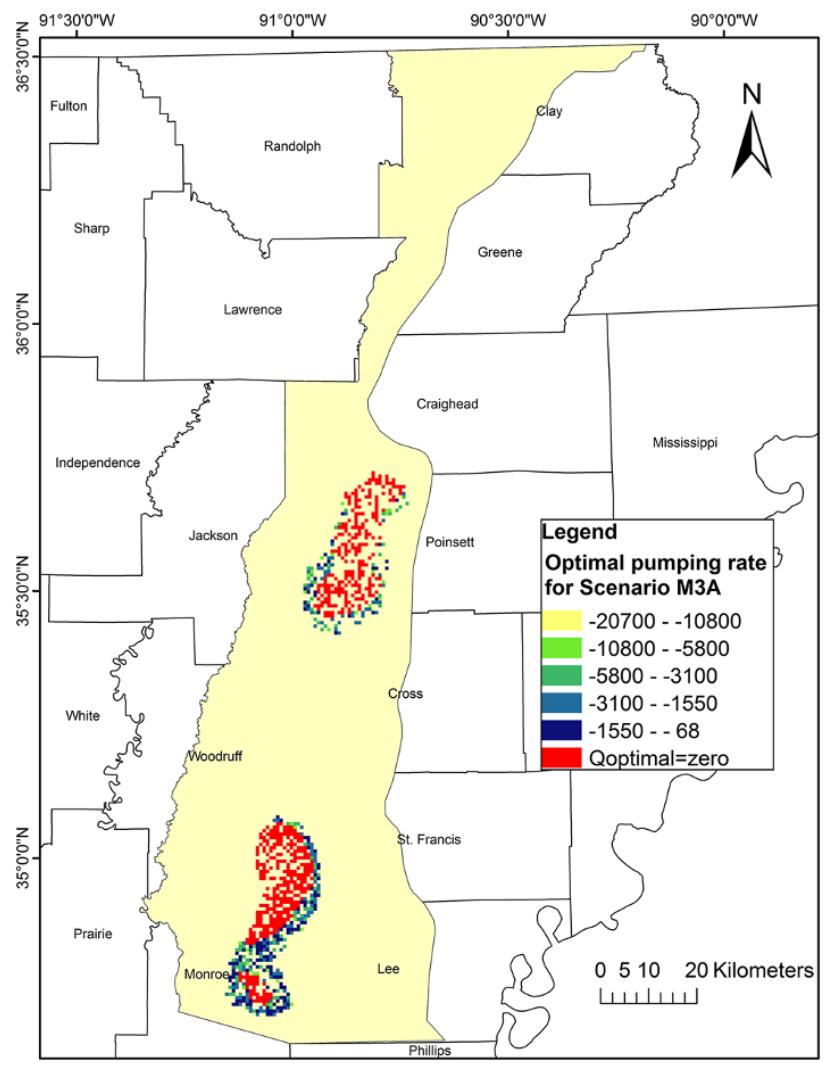

Fig. 12 Optimal pumping rate in $\mathrm{m}^{3} / \mathrm{d}$ for Sub-scenario 3A (134 min head constraints)

type (unconfined). SLP solves a series of linear programing subproblems, each formulated using the response matrix technique. In each iteration of the method, the response coefficients are calculated using a unit rate added to the current managed flow rates; the current managed rates are derived from the previous iteration's optimal withdrawal rates. The sequential process is continued until convergence is achieved. Two convergence criteria were specified to control the end of the SLP process. The first criteria, $\varepsilon_{1}$ (ranged 0.01-0.55), requires that the change in flow rate variable values from the prior iteration to the current iteration be less than a fraction of the magnitude of the flow rate variables at the current iteration. The second criteria, $\varepsilon_{2}(0.001)$, requires that the change in objective function value be less than a specified fraction of the magnitude of the objective function value. For most scenarios, three to four SLP iterations were required to meet these two criteria.

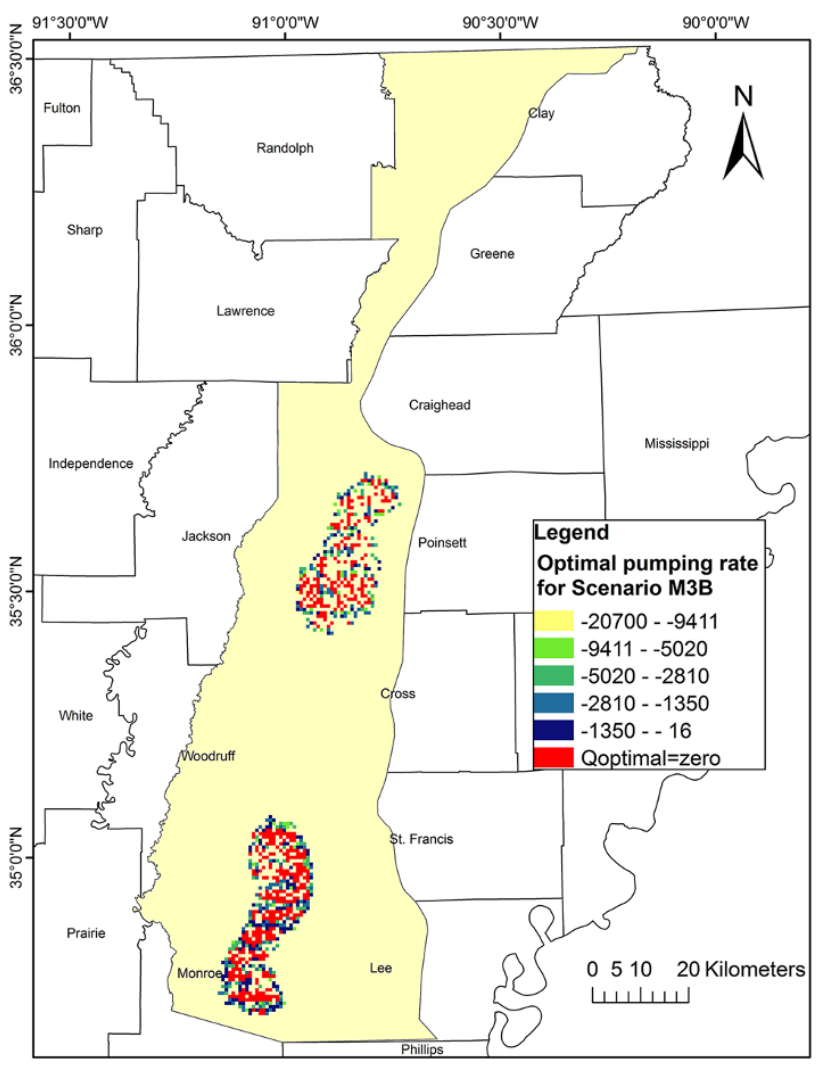

Fig. 13 Optimal pumping rate in $\mathrm{m}^{3} / \mathrm{d}$ for Sub-scenario 3B (134 drawdown constraints)

\section{Results}

A- Maximum pumping constraints for the managed wells equal to $100 \%$ of the pumping rate of the year 2010

The final optimal pumping results indicated that approximately 57 and $31 \%$ of the wells should be shut down in the case of minimum head constraints for Scenario 1 and Scenario 2, respectively; 18 and $16 \%$ of the wells should be shut down in the case of drawdown constraints for Scenario 1 and Scenario 2, respectively. The average optimal pumping rates for the managed wells from groundwater in the case of minimum head constraints were $0.59 \mathrm{Mm}^{3} / \mathrm{d}$ and $2.43 \mathrm{Mm}^{3} / \mathrm{d}$ for Scenario 1 and Scenario 2 , respectively, which are only about 41.66 and $60.24 \%$ of the amount withdrawn in 2010, respectively; 1.01 and $3.1 \mathrm{Mm}^{3} / \mathrm{d}$ in the case of drawdown constraints for 


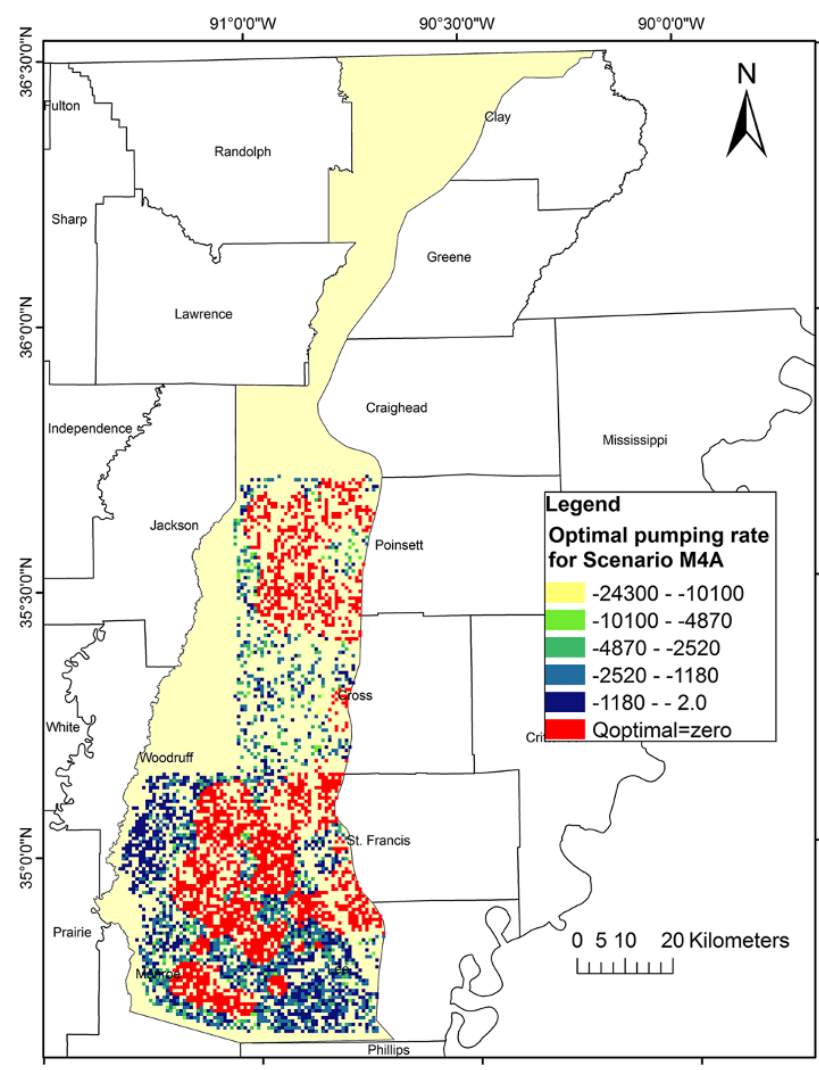

Fig. 14 Optimal pumping rate in $\mathrm{m}^{3} / \mathrm{d}$ for Sub-scenario $4 \mathrm{~A}$ (220 min head constraints)

Scenario 1 and Scenario 2, respectively, which are only about 71.42 , and $76.87 \%$ of the amount withdrawn in 2010, respectively. Figures 8, 9, 10, and 11 show the location of operating and shutdown wells with the optimal pumping rate.

B-Maximum pumping constraints for the managed wells equal to $200 \%$ of the pumping rate of the year 2010

The final optimal pumping indicated that approximately 65 and $50 \%$ of the wells should be shut down in the case of minimum head constraints for Scenario 3 and Scenarios 4, respectively; 50 and $47 \%$ of the wells should be shut down in the case of drawdown constraints for Scenario 3 and Scenario 4, respectively. The average optimal pumping rate for the managed wells from groundwater in the case of minimum head constraints was 0.88 and $3.28 \mathrm{Mm}^{3} / \mathrm{d}$ for Scenario 3 and Scenario 4, respectively, which are only about 62.21 and $81.32 \%$ of the amount withdrawn in 2010, respectively; 1.07 and $3.45 \mathrm{Mm}^{3} / \mathrm{d}$ in the case of drawdown constraints for Scenario 3 and Scenario 4,

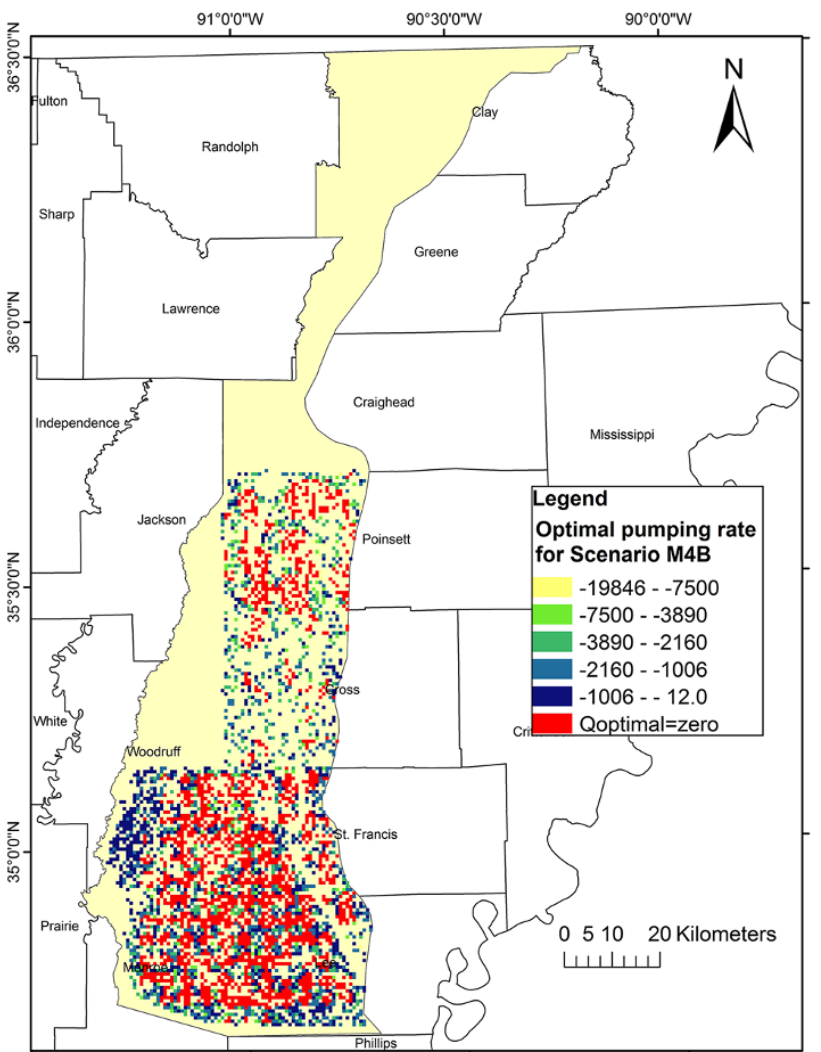

Fig. 15 Optimal pumping rate in $\mathrm{m}^{3} / \mathrm{d}$ for Sub-scenario 4B (220 drawdown constraints)

respectively, which are only about 75.83 , and $85.5 \%$ of the amount withdrawn in 2010, respectively. Figures 12, 13, 14 , and 15 show the location of operating and shutdown wells with the optimal pumping rate.

The percent increase of the volume of water stored in the aquifer using optimal pumping compared to the base scenario (simulated head for the year 2010) was calculated, and the maximum percent volumes were 4.3 and $3.7 \%$ for Scenario $2 \mathrm{C}$ and $2 \mathrm{~A}$, respectively, as shown in Table 1 . The spatial distribution of the simulated head difference of the optimal pumping rate for the managed wells was drawn for Scenario 2A and 2C due to the high increase in volume of water stored in the aquifer compared to other scenarios. The simulated head differences ranged from -1.8 to $8.8 \mathrm{~m}$ for the year 2010 as shown in Figs. 16 and 17. The results of optimal pumping for all scenarios are shown in Table 3.

\section{Conclusions}

The Cache area was designated as a critical groundwater area in 2009 due to the decline in its water level to below 


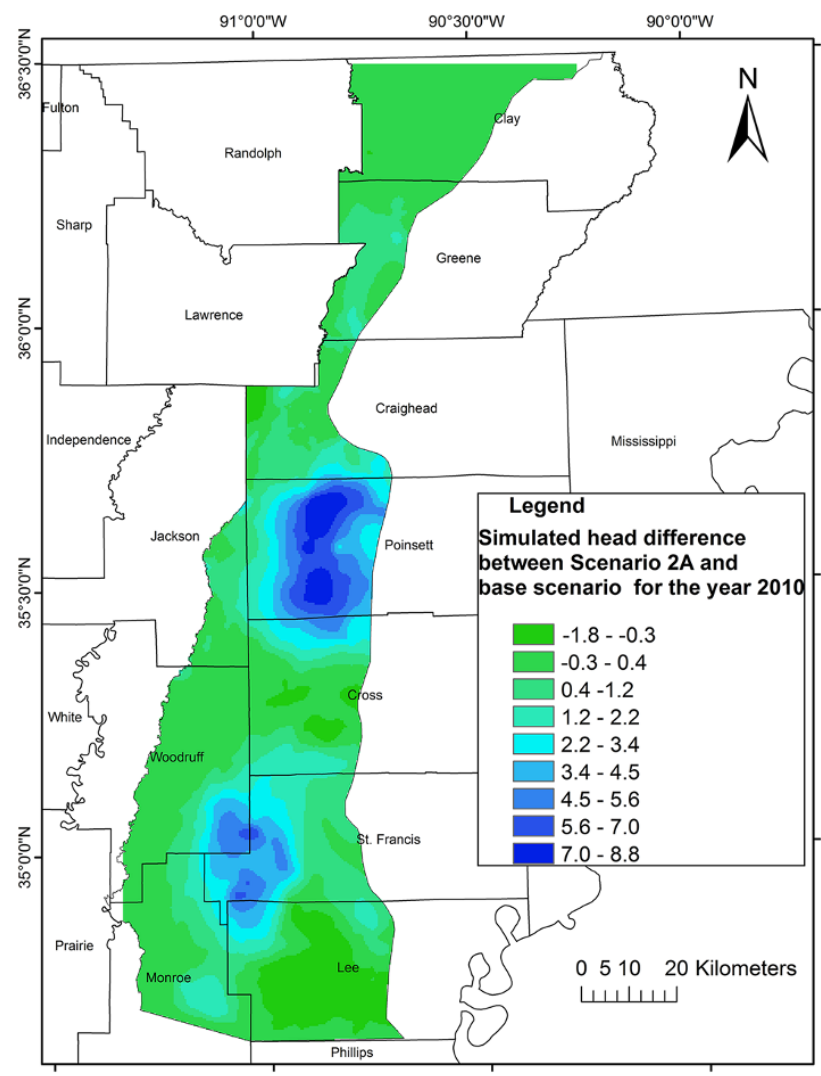

Fig. 16 Simulated head difference between Sub-scenario 2A and base scenario for the year 2010

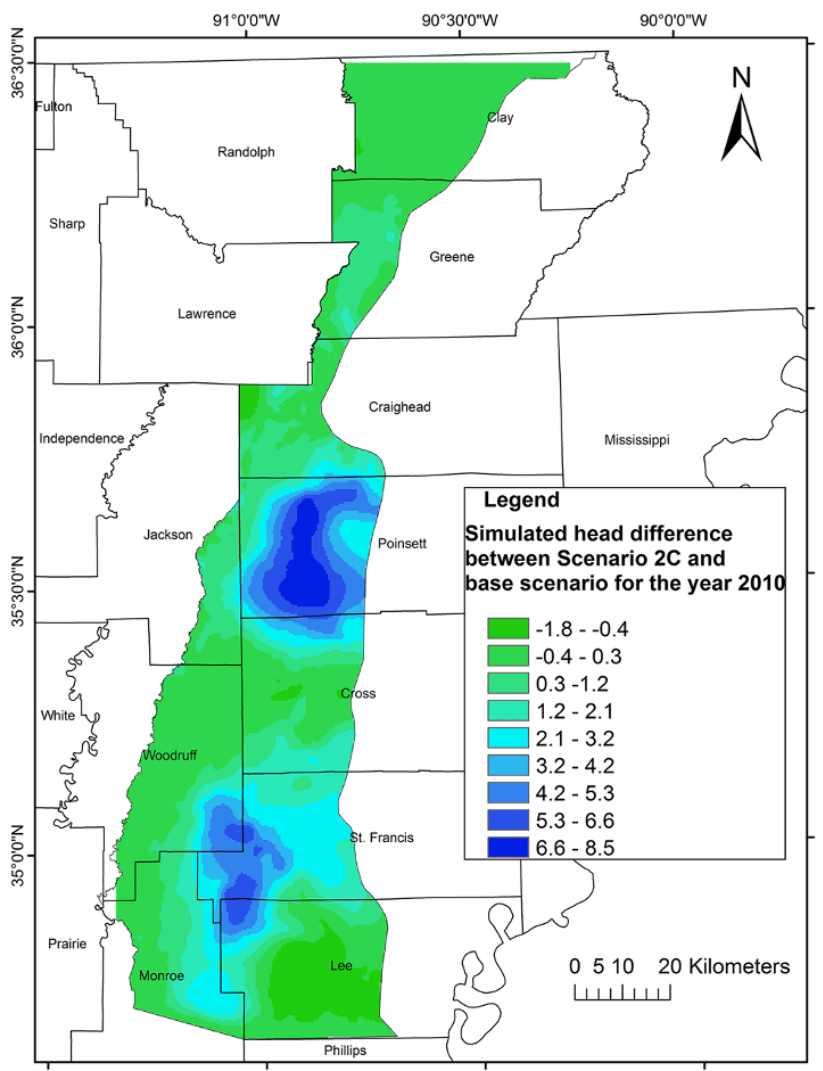

Fig. 17 Simulated head difference between Sub-scenario $2 \mathrm{C}$ and base scenario for the year 2010

Table 3 Optimal pumping result for 100 and $200 \%$ of the pumping rate for the year 2010, in which Hmin refers to minimum head constraints and Dd to drawdown constraints

\begin{tabular}{llllllll}
\hline $\begin{array}{l}\text { Sub- } \\
\text { scenario }\end{array}$ & $\begin{array}{l}\text { Constraints no. } \\
\text { and type }\end{array}$ & $\begin{array}{l}\text { No. of managed } \\
\text { wells }\end{array}$ & $\begin{array}{l}\text { Total Q2010 } \\
\left(\mathrm{Mm}^{3} / \mathrm{d}\right)\end{array}$ & $\begin{array}{l}\text { Total Qoptimal } \\
\left(\mathrm{Mm}^{3} / \mathrm{d}\right)\end{array}$ & $\begin{array}{l}\text { No. of } \\
\text { shutdown wells }\end{array}$ & $\begin{array}{l}\text { No. of } \\
\text { operating wells }\end{array}$ & $\begin{array}{l}\text { \% Volume of water } \\
\text { store increase }\end{array}$ \\
\hline 1A & 134-Hmin & 938 & 1.41 & 0.58 & 532 & 406 & 2.4 \\
1B & 134-Dd & 938 & 1.41 & 1.02 & 183 & 755 & 0.8 \\
1C & 260-Hmin & 938 & 1.41 & 0.60 & 545 & 393 & 2.3 \\
1D & 260-Dd & 938 & 1.41 & 1.00 & 161 & 777 & 0.9 \\
2A & 220-Hmin & 3,870 & 4.03 & 2.51 & 1,111 & 2,759 & 3.7 \\
2B & 220-Dd & 3,870 & 4.03 & 3.11 & 643 & 3,227 & 1.3 \\
2C & 436-Hmin & 3,870 & 4.03 & 2.34 & 1,284 & 2,586 & 4.3 \\
2D & 436-Dd & 3,870 & 4.03 & 3.08 & 615 & 3,255 & 1.4 \\
3A & 134-Hmin & 938 & 1.41 & 1.05 & 551 & 387 & 0.6 \\
3B & 134-Dd & 938 & 1.41 & 1.10 & 491 & 447 & 0.5 \\
3C & 260-Hmin & 938 & 1.41 & 0.71 & 676 & 262 & 1.5 \\
3D & 260-Dd & 938 & 1.41 & 1.04 & 446 & 492 & 0.6 \\
4A & 220-Hmin & 3,870 & 4.03 & 3.39 & 1,867 & 2,003 & 0.6 \\
4B & 220-Dd & 3,870 & 4.03 & 3.47 & 1,860 & 2,010 & 0.1 \\
4C & 436-Hmin & 3,870 & 4.03 & 3.16 & 2,008 & 1,862 & 1.8 \\
4D & 436-Dd & 3,870 & 4.03 & 3.42 & 1,758 & 2,112 & 0.4 \\
\hline
\end{tabular}


$50 \%$ of the saturated thickness of the aquifer. Optimization models were constructed to determine maximum optimal pumping of the irrigation wells located in the areas with cones of depression. The results indicated that the number of constraints has no significant effect on the optimal results. The number of shutdown wells increased by $14-188 \%$ in the case of the maximum pumping constraint specified as $200 \%$ of the pumping rate of the year 2010. In addition, the number of shutdown wells was more in the case of minimum head constraints compared with the drawdown constraints. The average optimal pumping increased by 6-49\% in the case of the maximum pumping constraint specified as $200 \%$ of the pumping rate of the year 2010; however, the percent of volume of water stored in the aquifer decreased as compared to the case of the maximum pumping constraint specified as $100 \%$ of the pumping rate of the year 2010. From the results, there is no relation between the optimal pumping rate, cell thickness, and the existence of the constraint in the cells that have been chosen as managed wells. In addition, the same managed well has a different optimal value for different decision variable groups.

Acknowledgments Mrs. Haveen Rashid is grateful to Mr. Brian Clark from the United States Geological Survey, Arkansas Water Science Center, Fayetteville Field Office for his help and continuous support during this research.

Open Access This article is distributed under the terms of the Creative Commons Attribution License which permits any use, distribution, and reproduction in any medium, provided the original author(s) and the source are credited.

\section{References}

Ahlfeld DP, Mulligan AE (2000) Optimal management of flow in groundwater systems. Academic Press, San Diego

Ahlfeld DP, Barlow PM, Mulligan AE (2005) GWM-a groundwater management process for the US Geological Survey Modular Ground-Water Model (MODFLOW-2000): US Geological Survey Open-File Report 2005-1072, p 124

Barlow PM, Ahlfeld DP, ASCE M, Dickerman DC (2003) Conjunctive-management models for sustained yield of stream-aquifer systems. J Water Resour Plan Manag 129(1):35-48

Broom ME, Lyford FP (1981) Alluvial aquifer of the Cache and St. Francis River Basin, Northeastern Arkansas: Open-File Report p 81-476

Czarnecki JB (2006) Simulation of Various Management scenarios of the Mississippi River Valley Alluvial Aquifer in Arkansas: US Geological Survey Scientific Investigations Report 2006-5052, p 14

Czarnecki JB (2008) Evaluation of Selected Model Constraints and Variables on Simulated Sustainable Yield from the Mississippi River Valley Alluvial Aquifer System in Arkansas: US Geological Survey Scientific Investigations Report 2008-5138, p 21

Czarnecki JB (2010) Groundwater-Flow Assessment of the Mississippi River Valley Alluvial Aquifer of Northeastern Arkansas: US Geological Survey Scientific Investigations Report 20105210, p 33
Czarnecki JB, Clark BR, Reed TB (2003a) Conjunctive use optimization model of the Mississippi river Valley alluvial aquifer of northeastern Arkansas :US Geological Survey Water Resources Investigation Report 03-4230, p 29

Engler K, Thompson DG, Kazmann RG (1945) Groundwater Supplies for Rice Irrigation in Grand Prairie Region, ARKANSAS: University of Arkansas, Agriculture Experiment Station Bulletin No. 457, p 56

Harbaugh A W, Banta E R, Hill M C, McDonald M G (2000) MODFLOW-2000, The U.S. Geological Survey modular ground-water model-user guide to Modularization Concepts and the Ground-Water Flow Process: U.S. Geological Survey Open-File Report 00-92, $121 \mathrm{p}$

Hill M C (1990) Preconditioned conjugate-gradient 2(PCG2), a computer program for solving ground-water flow equations: US Geological Survey Water-Resources Investigations Report 90-4048, p 25

Hill MC, Banta ER, Harbaugh AW, Anderman ER (2000) MODFLOW-2000, The US Geological Survey modular ground-water model-user guide to the observation, sensitivity, and parameterestimation processes and three post-processing programs: US Geological Survey Open- File Report 00-184, p 209

Kharmah RN (2007) Optimal management of groundwater pumping the case of the Eocene Aquifer, Palestine: M.S. Thesis, Department of Water and Environmental Engineering, Faculty of Graduate Studies, at Al-Najah National University, Nablus, Palestine

Maupin MA, Barber NL (2005) Estimated withdrawals from principal aquifers in the United States, 2000: US Geological Survey Circular 1279, p 46

Peralta R C, Yazdanian A, Killian PJ, Shulstad R N (1985) Future Quaternary groundwater accessibility in the Grand Prairie-1993: University of Arkansas, Agricultural Experiment Station Bulletin no. 877 , p 37

Peralta RC, Azarmniab H, Takahashic S (1991) Embedding and response matrix techniques for maximizing steady-state groundwater extraction1: computational comparison. J Ground Water 29(3):357-364

Peralta RC, Cantiller RA, Teny JE (1995) Optimal large-scale conjunctive water-use planning case study. J Water Resour Plan Manag 121(6):471-478

PRISM Group (2012) PRISM Group. http://www.prism.oregonstate. edu/products/matrix.phtml. Accessed 1 Mar 2012

Reed T B (2003) Recalibration of a ground-water model of the Mississippi River valley alluvial Aquifer of Northeast Arkansas, 1918-1998, With simulations of water levels caused by projected ground-water withdrawals through 2049: US Geological Survey Water Resources Investigations Reports 2003-4109, p 58

Reed T B (2004) Status of water levels and selected water-quality conditions in the Mississippi River valley Alluvial Aquifer in Eastern Arkansas, 2002: US Geological Survey Scientific Investigations Report 2004-5129, p 53

Schrader T P (2006) Status of water levels and selected water-quality conditions in the Mississippi River valley Alluvial Aquifer in Eastern Arkansas, 2004: US Geological Survey Scientific Investigations Report 2006-5128, p 82

Schrader T P (2008) Water Levels and Selected Water-Quality Conditions in the Mississippi River Valley Alluvial Aquifer in Eastern Arkansas, 2006: U.S. Geological Survey Scientific Investigations Report 2008-5092, p 72

Schrader T P (2010) Water levels and selected water-quality conditions in the Mississippi River valley Alluvial Aquifer in Eastern Arkansas, 2008: US Geological Survey WaterResources. Scientific Investigations Report 2010-5140

US Department of Agriculture (2010) The census of agriculture 2007 census publications. http://www.agcensus.usda.gov/Publications/ 2007/Online_Highlights/County_Profiles/index.asp. Accessed 8 Jul 2010 